\title{
Climate Management and Structural Ignorance in Ray Hammond's Extinction
}

\author{
Hakan YILMAZ*
}

\begin{abstract}
In his dystopian novel, Extinction (2005), Ray Hammond envisions an image of the world in the near future where it is troubled by an extreme form of climate management that enables multi-national corporations and governments from the wealthier regions of the world to control the climate and make profits by selling climate services to the rest of the world. The invasive climate management practices of the capitalist system represented by corporations and governments interfere with and disrupt the natural rhythms of the Earth systems to the extent of the latter's collapse. Moreover, the representatives of the capitalist self-prioritizing system such as the ERGIA Corporation and the US Government in the novel spread ignorance regarding the true nature of their practices by suppressing and/or obscuring scientific findings and evidence that prove the harmful effects of their relentless climate management. Accordingly, this paper aims at tracing the links between the perpetuated practices of the capitalist corporations and governments, and environmental degradation and collapse in Ray Hammond's Extinction which presents a world where advanced climate management systems have been implemented in space and weather events are tightly controlled and scheduled. It further discusses how the environmental cataclysms brought about by deep interference with the Earth's magnetic field via extreme climate management in the novel expose the self-interested and ruthless capitalist system's failure to see or rather deliberate ignorance of the detrimental and irreversible effects and consequences of large-scale climate management which drives the world to extinction.
\end{abstract}

Keywords: Ray Hammond, Extinction, Climate Change, Climate Management, Global Warming, Agnotology, Capitalism.

* Asst. Prof. Dr., Burdur Mehmet Akif Ersoy University, Faculty of Science and Letters, Department of Western Languages and Literatures, English Language and Literature, Burdur, Turkey.

Elmek: hknylmzz@gmail.com

https://orcid.org/0000-0002-6019-2214. 


\section{Ray Hammond'ın Extinction Romanında İ́klim Yönetimi ve Yapısal Bilmezlik}

\section{$\ddot{O ̈}_{z}$}

Extinction (2005) adlı distopik romanında, Ray Hammond, dünyanın daha zengin bölgelerinden olan çok uluslu şirketlerin ve hükümetlerin iklimi kontrol etmesine ve dünyanın geri kalanına iklim hizmetleri satarak kazanç sağlamasına olanak veren iklim yönetiminin aşırı bir formunun başına bela olduğu dünyanın yakın gelecekteki bir tasvirini yapar. Şirketlerin ve hükümetlerin temsil ettiği kapitalist sistemin istilacı iklim yönetim uygulamaları, yerküre sistemlerinin doğal ritimlerini, bunların çöküşüne varan ölçüde, sekteye uğratır ve bozar. Üstelik, romanda, ERGIA Şirketi ve Amerikan hükümeti gibi kendini önceleyen kapitalist sistemin temsilcileri, sonu gelmeyen iklim yönetimlerinin zararlı etkilerini kanıtlayan bilimsel bulguları ve kanıtları ortadan kaldırarak ve/ya karartarak, uygulamalarının gerçek yüzü ile ilgili bilmezlik yayarlar. Dolayısıyla, bu çalışma, ileri düzey iklim yönetim sistemlerinin uzayda kurulu olduğu ve hava olaylarının sıkı bir şekilde kontrol edildiği bir dünya sunan Ray Hammond'ın Extinction isimli eserinde, kapitalist şirketlerin ve hükümetlerin sürdürülen uygulamaları ile çevresel bozulma ve çöküş arasındaki bağlantıların izini sürmeyi hedeflemektedir. Ayrıca, romanda, aşırı iklim yönetimi sebebiyle dünyanın manyetik alanına yoğun bir darbe inmesi sonucu meydana gelen çevresel felaketlerin, dünyayı yok oluşa sürükleyen büyük ölçekli iklim yönetiminin zararlı ve geri dönüşü olmayan etkilerini ve sonuçlarını, çıkarcı ve amansız kapitalist sistemin görememesini ya da bundan ziyade kasıtlı görmezden gelişini nasıl açığa çıkardığını tartışmaktadır.

Anahtar Kelimeler: Artgönderim, Bağlama, Uzak-Ara Dönüşlü Adılları, Dönüşlülük, İkileme. 


\section{Genişletilmiş Özet}

Ray Hammond, Extinction (2005) adlı romanında, dünyanın daha zengin bölgelerinden olan çok uluslu şirketlerin ve devletlerin iklimi kontrol ederek ve iklim hizmetleri satarak gelir elde ettikleri bir dünya kurgular. Yakın gelecekte geçen roman, iklim yönetiminin aşırı bir şekilde uygulandığında ne tür etkileri ve sonuçları olabileceğini gözler önüne serer. Romanda, ERGIA gibi bir çok iklim yönetimi şirketlerinin pratikleri, yerküre sistemlerinin doğal akışının aksamasına ve hatta bozulmasına sebebiyet vermektedir. Tüm amacı daha çok kâr etmek olan söz konusu şirketler iklim yönetimi politikalarını uygularken bu konuda uzmanların yaptığı uyarıları 1srarla göz ardı etmektedir. Üstelik, uyguladıkları kâr odaklı iklim yönetimi pratiklerinin olumsuz etkilerini örtmek için hem şirketler hem de hükümetler bu pratikler ile ilgili gerçekleri saptırma ve/veya saklama yoluna giderler ve insanları bilerek yanıltırlar. İklim yönetimi şirketleri, insanlarda bu tür bir bilmezlik ve bilgisizlik yaratarak, sistematik bir biçimde, kendi pratikleri ve gün geçtikçe daha belirgin olan çevre sorunları arasında olduğu düşünülen tüm bağlantıları da reddeder. Bu şirketlerin (kasıtlı) bilmezliği, dünyanın ekolojik olarak içerisinde bulunduğu gerçek durumu gözler önüne seren bilimsel kanıtları ve bulguları kasten önemsizleştirme, karartma ve hatta yok sayma raddesine gelir çünkü ekonomi, özellikle de daha zengin ülkelerin ekonomisi, büyük ölçüde söz konusu çok uluslu şirketlerin sağladığı iklim yönetimine dayanmaktadır. Daha çok kâr yapma hırsıyla güdülenmiş bu ekonomik sistem, çoğunlukla tahmin etmesi kolay olmayan çevresel bozulmalara yol açmasına rağmen, ekonomik büyümeyi önceleyen yapısal bilmezliği sebebiyle, yerküre sistemlerinin maruz kaldığı bozulmaların ne boyutta olduğunu gör(e)mez. Bu açıdan bakıldığında, Ray Hammond'ın Extinction romanı, kapitalist ekonomik sistemin tek yaşam destek sistemimiz olan dünyamızı kaçınılmaz bir şekilde etkileyen edimlerinin ölümcül sonuçlarını gözler önüne sermekle kalmaz aynı zamanda okuyucuya söylenmemiş, gizlenmiş veya saptırılmış gerçekleri görebileceği ve kapitalist sistemin pratiklerinin nasıl ve ne oranda yerküre sistemlerini etkilediğini daha iyi kavrayabilmesini mümkün kılan bir bakış açısı da sunar. Hızla değişen bu zamanlarda, doğa ve ekosistemler, genellikle ilerleme ve gelişme adına sistemin uygulamaya koyduğu tüm kâr amaçlı pratikler ve bu pratiklerin zararlı ve önceden kestirilemeyen etkileri karşısında en savunmasız kalan varlıklardır 
çünkü söz konusu etkiler yerküre sistemleri için tamiri mümkün olmayan hasarlara yol açarak bu sistemlerin tümden çöküşüne sebebiyet verme potansiyeline her zaman sahiptir. Böylelikle, bu çalışma, Ray Hammond'ın Extinction adlı romanında, kapitalist şirketlerin ve hükümetlerin temsil ettiği ekonomik sistemin bilmezlikten gelen ve sürdürülen pratikleri ile çevresel bozulma ve ekolojik çöküş arasındaki bağlantıları ve ilişkileri incelemeyi ve ortaya koymayı amaçlamaktadır. Üstelik, romanda aşırı bir şekilde uygulaması yapılan iklim yönetiminin dünyanın manyetik alanında bozulmalara yol açması sonucu meydana gelen çevresel felaketlerin, kendine hizmet eden ve acımasız kapitalist sistemin dünyayı yok oluşa sürükleyen büyük ölçekli iklim yönetiminin döndürülemez etkileri ve sonuçlarını görememesini veya bundan ziyade kasıtlı bir şekilde görmeyi reddetmesini nasıl açığa çıkardığı tartışılacaktır. Ayrıca, Hammond'ın Extinction romanı gibi ekolojik yönü kuvvetli olan eserlerin, kapitalist ekonomik sistemin bilmezlik yaratmak ve yaymak için kullandiğı stratejik taktikleri ve girişimleri görmemizi, anlamamızı ve gerçekte neyi amaçladıklarını kavramamızı sağlayabilecek bir potansiyel barındırdığı gösterilecektir. Ekolojik yönü ağır basan söz konusu anlatıları felaket tellallığı olarak görmek yerine çoktan ciddiye almamız gerektiği sonucuna varılacaktır çünkü sistemin bilmez pratikleri ve bilmezlik yaratması ve yayması devam ederse şayet, Hammond'ın romanında yaşanan çevresel yıkımların günümüzden çok uzakta olmadığı görülecektir. Bu yüzdendir ki ekolojik anlatılar, sadece birer hayal ürünü olmaktan ziyade, gerçekleşmesi oldukça muhtemel birçok ekolojik olgu üzerinde durarak aynı zamanda ekolojik bir bilincin oluşmasında çok önemli bir rol oynar. Günümüzde küresel ısınma, yükselen deniz seviyeleri, artan dip su sıcaklıkları gibi romanda detaylı bir şekilde ele alınan birçok çevre sorununun hâlihazırda zaten ürkütücü seviyelere ulaştığı göz önüne alındığında, çevresel yıkıma karşı harekete geçmek ve ekolojik farkındalık yaratmak için, Hammond'ın romanı gibi anlatılara ihtiyacımız vardır çünkü nihayetinde ekolojik anlatılar içinde bulunduğumuz dünyanın maruz kaldığı kapitalist ekonomik sistemin amansız pratikleri sonucu dönüşebileceği suretleri kurgulayarak bizlere birer öngörü sunmakla kalmaz dünya ile ilişkimizi yeniden gözden geçirmemizi mümkün kılar. 


\section{Introduction}

In his prescient dystopian work, Extinction (2005), Ray Hammond envisions a world that has already undergone a significant body of changes due to global warming. Many people have already lost their homes to rising sea levels in the novel and are now forced to live on old tankers or hulks on the open seas because wealthy nations refuse to welcome these environmental refugees into their countries. These "hulk communities," as the environmentally displaced people are referred to in the novel, are, instead, pushed to "the bottom of the world, in the Southern Ocean, 1,500 miles south-east of New Zealand" (Hammond 2005: 2) where they suffer from terrible weather conditions and dire living circumstances, whereas the richer countries that can afford climate management services provided by capitalist corporations can adjust climate according to their needs. However, the implementation of climate control systems (particularly solar reflectors) on such a large scale to produce desired weather conditions begins to take its toll on the Earth systems. Various ecological disasters begin to occur in the form of earthquakes, volcanic eruptions, and tsunamis that largely damage the regions where they happen. The ERGIA Climate Management Corporation run by Nicholas Negromonte controls the climate and sells regionspecific weather conditions to nations all around the world. With their solar reflectors set up in space, this company along with other climate management corporations can produce rain, sunlight, wind, etc., and thus play with every aspect of the climate. The visible and detrimental consequences of this company's interference with the Earth systems are repeatedly ignored by both the company itself as well as the American government which has established close links with the former for funding. The unbridled profit-driven practices of the capitalist corporations in the novel lead to many unprecedented environmental catastrophes around the world. In this paper, I will trace the links and correlations between the perpetuated ignorant practices of the system represented by capitalist corporations and governments, and environmental degradation and collapse in Ray Hammond's Extinction. I will further argue that the environmental cataclysms brought about by deep interference with the Earth's magnetic field via extreme climate management in the novel expose the self-interested and ruthless capitalist system's failure to see or rather deliberate ignorance of the harmful and ir- 
reversible effects and consequences of large-scale climate management which drives the world to extinction.

\section{Climate Management and Ignorance in the Making in Extinction}

The futuristic world Extinction presents is controlled by techno-scientific capitalist corporations that, as it were, run the climate of the world with their climate management technologies. Climate management is part of the recently bourgeoning field of geoengineering which indicates "the deliberate large-scale manipulation of the planetary environment to counteract anthropogenic climate change" (Shepherd 2009: 1). Although there is still no geoengineering technology developed enough to be extensively used today, there are two main branches of geoengineering that attempt to offer solutions to the problem of climate change from different angles: Carbon Dioxide Removal (CDR) and Solar Radiation Management (SRM). As Thornes and Pope put it, while "CDR technologies aim to reduce climate change by removing greenhouse gases from the atmosphere," SRM techniques intend to "decrease the effects of climate change by reducing the amount of energy within the Earth system by reflecting a proportion of solar radiation back to space" (2014: 20). The technology used in the novel for climate control is the fully-fledged and much more advanced version of space-based SRM schemes that have been proposed since the 1990s such as setting up sunlight deflectors and mirrors in space. Although the research and development costs of space-based methods make them "unlikely to be feasible in the medium term" (Shepherd 2009: 36), climate management which is reportedly introduced in Europe in 2031 in the novel (Hammond 2005: 187) is the most competitive and invested sector where Nicholas Negromonte's ERGIA Climate Management Corporation is the leading player. The ERGIA Corporation and the like offer climate services to governments and other companies (for instance, insurance companies) by using orbiting solar reflectors in space: "By reflecting concentrated sunlight onto the upper atmosphere, the ERGIA Corporation and its competitors could regulate the temperature and altitude of the stratospheric winds. This allowed whole weather systems to be seeded, grown, aborted, directed or dispersed" (Hammond 2005: 15). With their highly advanced technological means and techniques including "atmospheric inversion, wind steering, tornado nudging, cloud seeding and slow-ocean warming" (Hammond 2005: 188), the corporations can manipulate the weather and climatic events in accordance with demands coming from governments and other companies. In addition, 
these techniques enable them to adjust the local climate, based on the needs of any given region (e.g. providing shade over polar ice caps and/or other regions that run the risk of overheating due to global warming). Being "the world's dominant service supplier of managed weather" (Hammond 2005: 191), the ERGIA Corporation even develops "the latest, and by far the largest, solar-reflector project" called LunaSun which allows them to establish 42,000 solar mirrors on the surface of the moon. This project is sanctioned by the United Nations which "grant the ERGIA Corporation a unique license to utilize a tract of the Earth-facing lunar surface for solar capture" (Hammond 2005: 18). Climate control as such was initially introduced as a way to set on track the derailed course of climate change and "manage away the worst effects of global warming" (Hammond 2005: 14), but it turns into a very profitable sector before long.

However, ironically enough, many of the capital-driven climate management corporations in the novel were at first oil, gas, and coal providers. Today, according to the IPCC 2014 report, population growth and, more importantly, economic growth linked to fossil fuel combustion seem "to be the most important drivers of increases in CO2 emissions," hence global warming (IPCC 2014: 5). In the novel, when the practices of the former fossil fuel companies were too much for the Earth to bear, they changed sectors and started, this time, selling climate services to mitigate the impact of global warming. Put differently, they are the very companies that initially triggered global warming with their relentless and damaging practices. When the effects of these were too obvious to ignore, they turned to the newly burgeoning climate management industry to make money under the pretext of countering global warming. Nevertheless, as Thornes and Pope warn, the potential benefits of climate geoengineering "need to be carefully weighed against the detriments. A true assessment of geoengineering cannot be achieved until we better understand the environmental, technological, economic and governance issues, associated through its use" (2014: 20). While implementing their climate management policies whose sole purpose is to procure more capital, the corporations in Extinction ignore many of the warnings both discernible in natural patterns and coming from experts in the field. Despite their sustained efforts to control the climate and tightly schedule weather, there still take place unpredictable weather events that baffle them and the public. For instance, on a Thursday evening scheduled to be "dry and fine" and "sunny and hot," it pours down in San Francisco, spoiling many of the activities arranged for a sunny weather (Hammond 2005: 41). Similarly, on the other side of the world, in Independent Samoa, "the 
formerly idyllic weather had become far too unpredictable" (Hammond 2005: 21). These unpredictable occurrences along with large-scale tectonic movements, volcanic eruptions, earthquakes, and tsunamis in the remainder of the novel are closely linked to prevalent global warming, rising sea levels, ocean warming, and disturbances in the Earth's magnetic field (due to climate management) which are being documented by various scientists in the novel but ignored by corporations and governments. Their ignorance in this sense goes so far as to intentionally downplay, dismiss, and even obscure scientific evidence and findings that attest to the real situation the world is in. It is thus necessary to unpack and critically analyze these maneuvers by capitalist corporations so as to arrive at a fuller understanding of how ignorance is perpetuated, and what kind of repercussions such ignorance might have for the Earth systems.

The persistent ignorance engendered throughout the novel can be explicated with specific reference to the term "agnotology." Agnotology is a concept coined by Iain Boal, a linguist, who was asked by Robert N. Proctor, a historian of science, in the early 1990s to come up with a word to refer to "the historicity and artifactuality of non-knowing and the non-known - and the potential fruitfulness of studying such things" (Proctor 2008: 27). It is derived from the Greek word agnosis which means lack of knowledge or ignorance, and thus designates "the study of ignorance making," that is, "how ignorance is produced or maintained in diverse settings, through mechanisms such as deliberate or inadvertent neglect, secrecy and suppression, document destruction, unquestioned tradition, and myriad forms of inherent (or avoidable) culturopolitical selectivity" (Proctor and Schiebinger 2008: vii). Accordingly, it interrogates how ignorance is made and spread through various social, cultural, and scientific means that might help circulate certain deceptive ideas or data, and continually strive to contest and invalidate facts. These attempts are generally made in the name of protecting the capitaldriven system which is inclined to manipulate and falsify facts in accordance with its economic interests, and instead offer its own fabricated facts to preserve the status quo. "[S]tructural production of ignorance" (Proctor 2008: 3) is integral to self-prioritizing systems like capitalist corporations and governments as seen in their suppression and/ or obscuration of information to preempt any latent resistance to the implementation of their highly profitable and yet environmentally destructive practices. Such ignorance making pervasive in the system might lead to irreparable environmental deterioration the degree of which is, for the most part, not easy to predict because the system is fundamentally guided by monetary motives which preclude it from seeing the harm caused 
by its structural ignorance. In these rapidly changing times, nature and ecosystems seem to be the most vulnerable entities to the deleterious and unpredictable effects of the system's practices which are made mostly in the name of progress and which have come to damage the planet Earth to the extent of irreparability and imminent collapse.

Arguing against the common understanding of ignorance simply "as something in need of correction, a kind of natural absence or void where knowledge has not yet spread," Robert Proctor further contends that ignorance might be engendered variously by "censorship, disinformation . . . neglect, forgetfulness, myopia, extinction, secrecy, or suppression," and roughly makes three distinctions: "ignorance as native state (or resource), ignorance as lost realm (or selective choice), and ignorance as a deliberately engineered and strategic ploy (or active construct)" (2008: 2-3 emphases original). The third one configures
ignorance - or doubt or uncertainty - as something that is made, maintained, and manipulated by means of certain arts and sciences. The idea is one that easily lends itself to paranoia: namely, that certain people don't want you to know certain things, or will actively work to organize doubt or uncertainty or misinformation to help maintain (your) ignorance. (Proctor 2008: 8)

In light of such ignorance making or what Proctor calls "agnogenesis" (Proctor 2008: 8) at its best, climate management corporations in Extinction systematically deny any correlation between their extreme practices and the environmental perturbation that is becoming more and more visible, and instead argue that there is no scientific evidence that corroborates the damage their actions reportedly inflict on the Earth. However, the evidence that proves the connection between climate control and the disruption of the Earth systems has been suppressed by the US government and the ERGIA Corporation in the novel. Robert Fivetrees, a stellar planetary geophysicist in the novel, collects and analyzes the data from the Jesuit observations and compares them to the historical climate records only to arrive at the conclusion that there is a strong evidence that confirms the weakening of the Earth's magnetic field-which in turn leads to seismic events all around the world in the form of tremors, earthquakes, and volcanic eruptions. The motion of the liquid iron outer core of the Earth naturally creates a magnetic field that "shield[s] the life on the planet from the harmful effects of cosmic radiation" coming from the sun (Kilifarska-Bakmutov et al. 2020: 1). And Fivetrees' research finds that this protective shield is being increasingly incapacitated due to extreme climate management practices: 
My analysis proves that there is a direct link between electrical activity in the magnetosphere, the planet's climate, and the degree of seismic unrest. Stronger magnetic fields in the ionosphere directly weaken the magnetic fields produced by the dynamo of the Earth's molten core - the two are totally interdependent - and when you start artificially changing the climate around the planet, you weaken the magnetic fields being produced inside the Earth. The result is that the mantle flows are disrupted and you get a sudden increase of seismic events in the Earth's crust. (Hammond 2005: 104)

Fivetrees further predicts that if the extreme forms of sunlight harvesting via solar reflectors continue to be used, the magnetic poles of the Earth might reverse or flip, resulting in something "totally catastrophic, something that would qualify as what biologists call an "extinction event" (Hammond 2005: 106). Hammond's futuristic projection of such a possibility of the disruption of the magnetic field does seem to be a possible scenario given the recent research on the motion of the magnetic poles. Surendra Adhikari and Erik R. Ivins, two NASA geophysicists from Jet Propulsion Laboratory, California Institute of Technology, have found a correlation between climate change and the sudden turn of the direction of the north magnetic pole which they refer to as "climate-driven polar motion" (2016: 1).

The strong evidence Fivetrees finds is readily ignored and suppressed by the US government when he wants to publish his findings in the US Geophysical Review. He is immediately served "an emergency secrecy order" by the US government on the grounds of "a matter of national security," and is not only prevented from publishing his research, but also accused of "being unnecessarily alarmist" (Hammond 2005: 102, 106). Fivetrees sees the real reason behind the government's attempt to silence him as deriving from an economic interest:

Politicians are now too scared to relinquish climate management ... All of the developed economies in the world have become totally dependent on tightly scheduled weather patterns - energy consumption and production is now wholly geared to it. If governments suddenly banned climate control, industries like tourism, agriculture, insurance and energy would be set back by decades, with colossal losses. Worldwide recession would follow - and no politician holding office is going to risk that. (Hammond 2005: 106)

The economy, especially that of the wealthier countries, largely depends on climate management provided by multi-national corporations, and this new world order 
is bound by the proper operation of each cog in the machine. The Australian ecofeminist Val Plumwood locates the problem in the working of the system itself, arguing that "the system is self-prioritizing and has eliminated ... political, scientific and other potentially critical and corrective systems ... [and] it has little capacity to reflect on or correct its increasingly life-threatening failures and blindspots" (2002: 16). In this regard, governments and corporations privilege the proper working of the system over "the health and soundness of Nature" in Thoreau's words (2008: 53). For them, these money-making practices should continue to be carried out even at the expense of the collapse of the only life-support system for humans and all other life forms. Both the US government and the ERGIA Corporation CEO Nicholas Negromonte dismiss Fivetrees as "a troublesome crank" (Hammond 2005: 106) and his claim "a crackpot idea" (Hammond 2005: 200), and thus ignore his warnings. Driven by greed to make more capital, the economic system is blinded on its path to economic growth which "depends on the existence — and the active production — of human and extrahuman natures whose costs of reproduction are kept 'off the books"' (Moore 2017: 606). This is why some critics like Jason W. Moore and Andreas Malm increasingly refer to the epoch we live in today as "the Capitalocene," namely, "the earth under the rule of capital" (Altvater 2016: 146), and these scholars evaluate the current economic system "as a system of power, profit, and re/production in the web of life" (Moore 2017: 606). In the novel, an extreme form of this profit-driven system clearly finds expression in Negromonte's latest project called LunaSun. This project turns the surface of the moon into an immense field of sun reflectors the profits of which will be used to "begin climate modification on Mars. They're going to melt polar ice and stimulate oxygen production by planting GM crops specially designed for Martian conditions. ERGIA's long-term aim is to sell Martian real estate" (Hammond 2005: 142). Given the amount of money at stake, it is no surprise that this corporation goes any length to stay on course and suppress any protest that might do damage to its business.

Similarly, other threats that pose problems for the capitalist system and the political institutions in the novel are also promptly quelled by the staunch guardians of the system. Highlighting such political and economic interrelations, Michael Lazarus and Harro van Asselt write that in our present age "carbon-intensive investments create dependencies, political and institutional interests, and economic advantages that make it more difficult to move to lower-carbon pathways and thus reduce climate risks" (2018: 3). If to translate this position to the new world order presented 
in the novel, climate management investments engender a similar set of political and economic dependencies and entanglements. The system thus attempts to neutralize any resistance and/or threat to such interdependent relations. For example, Carole Gonzaga, the protagonist Michael Fairfax's ex-girlfriend, is a member of Planet First Organization which is considered a terrorist organization due to its militant activities to draw attention to environmental degradation caused by the practices of climate management corporations. Accused of being an "eco-terrorist" (Hammond 2005: 60), she is arrested and placed in Lompoc State Penitentiary from where she calls Michael and entreats him to visit her. Upon Michael's visit, she tells him about Fivetrees' findings about the disruption of the Earth's magnetic field and asks him to help Fivetrees find a legal way to bypass the national secrecy order placed on him and publish his research (Hammond 2005: 80). During the conversation, she also says that she will not seek bail and instead will represent herself in the court: "I intend to make a statement from the witness box, and tell the world in open court - where they can't stop me-what our government is covering up" (Hammond 2005: 80). When Michael tries to contact her later via telephone, the officer at the penitentiary tells him that she committed suicide by hanging herself in her cell. In the meantime, the government detains Dr. Emilia Knight, a seismologist working for “the world's leading seismic prediction" company GeoHazard Labs (Hammond 2005: 33), in a naval hospital in a military base in San Diego, citing as a reason her exposure to a highly radioactive piece of rock spurted out from the depths of Mount Mariota in Independent Samoa during its eruption. All these events take place suspiciously after Michael reveals in a press conference that he will bring a class action against the multi-national corporations in the Court of International Civil Justice in The Hague, the Netherlands - which was established "[f]ollowing decades of environmental, social, and economic abuse by corporations in all corners of the planet . . . to administer corporate justice" (Hammond 2005: 24). Michael mentions Fivetrees' and Knight's findings during the press conference without giving away their names and says that they are willing to testify in the court shortly after which Fivetrees is killed in a staged car accident and Dr. Emilia Knight is kept away against her will in a naval hospital. Michael is "very suspicious about all this" because he is "losing witnesses so fast [that] it's unnatural" (Hammond 2005: 182). Thus, the self-prioritizing capitalist system is ruthless when it detects a potential danger that might spoil its otherwise highly lucrative run. By eliminating any risk that might turn against it and obscuring the evidence that would expose the truth about its environmentally catastrophic practices, the system purposefully per- 
petuates ignorance and keeps people in the dark which is, in Robert Proctor's words, "an actively engineered part of a deliberate plan" (2008: 9).

The system prioritizes its survival and growth at the cost of the ecosystems and justifies this prioritization in the name of development and progress. It takes its cue from the "presumption to know the natural world scientifically, to manipulate it technologically and exploit it economically, and thereby ultimately to create a human sphere apart from it in a historical process that is usually labeled "progress"' (Heise 2006: 507). The progress humankind has achieved in the first half of the twenty-first century in the novel is remarkable in its adherence to unrestrained development in science and technology. With the help of innumerable sensors scattered across the world and in space, companies track the tectonic activities of the Earth, weather patterns, and deep-sea temperatures. For instance, GeoHazard Labs is one such company that tracks and predicts seismic occurrences around the world, and makes money out of selling predictions. Likewise, Nicholas Negromonte's ERGIA Corporation along with its competitors will be controlling the climate of "about seventy percent of the main land masses" in the world, especially after its LunaSun project starts operating (Hammond 2005: 199). In a sense, as Greg Garrard puts it, “[d]eploying science allowed [the corporations] to claim to speak for the whole world, a process called "scientification"' (2004: 168). The approach of these companies takes the direction of using science to support their claims and practices. In a Baconian way, they penetrate into the depths of the Earth systems and map out the inner workings of the ecocycles to better implement the changes that they want to make to the ecosystem and achieve desired ends, and at times use this procured knowledge to circumvent undesired circumstances.

The deployment of science generally helps capitalist corporations strengthen their position and gives them the upper hand in manipulating public opinion about their practices. As Robert Proctor puts it, "[i]gnorance can be made or unmade, and science can be complicit in either process" (2008: 3). Indeed, when speculation about the potential relation between climate control and tectonic events that have started to happen around the world goes wild in the novel, the US President James Underwood asks Negromonte, the CEO of the ERGIA Corporation, if there really is any connection between these two seemingly unrelated phenomena. The latter responds as follows:

We've grilled our own scientists, sir - they come from the world's most prestigious universities. None of them can see any link whatsoever. That was just a 
crackpot idea-although I gather the poor man who dreamt it up is now deadkilled in a car accident. (Hammond 2005: 200)

In addition, during an interview with Perdy Curtis from BBC, Negromonte dismisses such claims as "wild theories" as well as mere "media concoction" (Hammond 2005: 192). Negromonte's attitude is redolent of that of climate change deniers in the 1990s and early 2000s who, in the form of government administrations like the George W. Bush administration, industry tycoons, and certain research institutes like the George C. Marshall Institute in the USA, repeatedly "emphasiz[ed] the uncertainties rather than the accepted and established scientific relations" and, "insisted that the evidence of global climate change is uncertain, incomplete, insufficient, or otherwise inadequate" (Oreskes and Conway 2008: 60). Likewise, Negromonte not only repudiates any claim of a possible link between climate services and environmental degradation, but also argues that climate management as the latest scientific accomplishment is beneficial for everyone: "The choice is whether we control things to prevent the worst effects of this warming, or whether we just stand by and allow Mother Nature to flood yet more of our cities and coastlines" (Hammond 2005: 191). In an effort to swing the public opinion, he announces that his company is planning to “provide thirteen percent of LunaSun's output free of charge for distribution by the United Nations. Hundreds of millions of the world's poorest people will now be able to benefit from ERGIA Climate Management Services, with our compliments" (Hammond 2005: 193). Negromonte attempts to give the impression of a philanthropist while, in fact, his company and the like were fossil-fuel energy companies in the first place and largely contributed to global warming and rising sea levels, and now continue to do so with their new climate services. Their practices made millions of people lose their homes and land because of floods, thereby causing the formation of hulk communities.

In his private meeting with President James Underwood, Negromonte reveals his real intentions when he says that "[w]e want everyone to think this [LunaSun project] is beneficial for the whole world" where it is in fact just "another example of American capitalistic colonialism" (Hammond 2005: 199). In a sense, although they market their practices under the disguise of philanthropy, the projects developed by Negromonte's company and other corporations are solely driven by economic interest. As such, the prevalent capitalist system is, in Val Plumwood's words, "sado-dispassionate" (2002: 36 ), that is, stripped of all emotion and compassion. With its prioritization of economic 
development over and against everything else, the system either fails to recognize or, more likely, deliberately tends to overlook the damage it inflicts on many communities and the planet Earth because it is "devoted to maximum productivity and the unbridled assertion of human dominance" (Roszak 2003: 33). The so-called productivity or progress benefits only a small number of people or nations, while causing destruction and poverty elsewhere (mostly in the poorer regions of the world). For instance, as the narrator reveals at the beginning of the novel, "climate management techniques" are only "routinely applied to the wealthier regions of the planet" (Hammond 2005: 2), while the rest of the world suffers from their effects. This is why, as Malcolm Sen argues, we should "place power relationships at the center of analysis and [should not] overlook economic and developmentalist issues which are often embroiled within environmental ones" (2009: 366). Since its inception, climate management has gradually become so integral a part of the economy that these corporations know it is impossible to go back despite the increasing uncertainty regarding the impact of their practices. When the US President, for example, tells Negromonte that he would "have to shut [them] all down" if there were any connection between the natural disasters and climate control, Negromonte is well aware that the president's "threat was merely bravado - there wasn't a serving government on Earth that would risk depriving the electorate of its managed weather. Not only would voters hate reverting to an uncontrolled climate, the world economy would be plunged into chaos" (Hammond 2005: 200). Moreover, it is not just the world economy that would suffer from returning to a previous uncontrolled climate, but also the president himself because he is "very keen to become the first AfricanAmerican President of the United States to secure a second term in office" (Hammond 2005: 238-239), and his party has received "the largest single donation ever made to a political re-election campaign” from Negromonte's company (Hammond 2005: 135). Accordingly, the president not only endorses the ERGIA Corporation's LunaSun Project, but also "agree[s] to officiate at the formal opening" of the "moon energy facility" in return for this donation (Hammond 2005: 135). In this respect, all decisions and actions taken by both governments and corporations are fundamentally girded by economic interests that bind and entangle different powerful players on the scene to take the same side. As such, they become the gatekeepers of the capitalist system because ultimately they are the ones who financially benefit from it the most.

Drawing attention to the vulnerability of the Earth, Theodore Roszak writes that "we have an economic style whose dynamism is too great, too fast, too reckless 
for the ecological systems that must absorb its impact" (2003: 33). Indeed, the capitalist economic order embodied by huge corporations like the ERGIA Corporation in the novel interferes with the Earth's self-sustaining system and disrupts its operation with its uninhibited lethal practices - which ultimately triggers a chain of natural cataclysms. The novel opens into a world that is already troubled by global warming and rising sea levels precipitated by fossil-fuel energy industries over the last century. Early in the novel, we learn that the rising oceans have "swallowed nearly all of the beaches" of Independent Samoa and "also contaminated most of the islands' scant ground-water reserves . . . and now this remote nation was almost wholly unvisited and its coastal inhabitants had been driven from their homelands" (Hammond 2005: 22). Many other places across the world have been submerged under water because of floods caused by global warming. Also, deep-sea temperatures in the Pacific Ocean have "soared by almost two degrees in a single year" (Hammond 2005: 47), which means that a great number of coastal regions will also be inundated soon. Besides the alarming sea levels, the narrator also reveals that "in recent times the annual number of non-climatic hazardous events such as earthquakes and volcanic activity had more than doubled" (Hammond 2005: 36). These early signs of other imminent catastrophes to take place later in the novel mean nothing to the capitalist corporations because they are committed supporters of "a radical free market ideology opposing any kind of restriction on the pursuit of market capitalism, no matter the justification" (Oreskes and Conway 2008: 77). Therefore, all of these events are the early yet highly distinctive warnings that corporations and governments relentlessly ignore for the sake of economic gains.

Proposing a "supply-side policy" geared towards regulating the fossil fuel suppliers' practices, Michael Lazarus and Harro van Asselt argue that this approach "requires examination of how fossil fuel markets work, how fossil fuel interests are entangled with national governments, and who stands to win or lose with the introduction of constraints on fossil fuel production" (2018: 10). When these pertinent questions are considered, Hammond in Extinction explores a scenario in which supplyside policies have evidently failed to be implemented, and thus exposes who stood to lose. One of the most significant consequences of this failure to implement supplyside policies in the novel is the formation and victimization of hulk communities that consist of millions of "environmentally dispossessed [people] scattered across - but tightly corralled within - the angry seas of the unpopulated southern latitudes" (Ham- 
mond 2005: 10). They lead their lives under terrible conditions with no proper food, drinking water, medicine, and shelter because they are not allowed to approach any coast. As the narrator says,

the member states of the United Nations still refused to grant these masses any rights to asylum, rights from which so-called 'political' emigrants benefited automatically. These refugees, all victims of extreme global warming, were the 'unofficials' that no nation was prepared to welcome onto its shores. (Hammond 2005: 7)

Today, the definition of "refugee" introduced by the United Nations in 1951 is still in use and basically revolves around the idea of political persecution which justifies seeking asylum. Despite many calls in the late twentieth century and early twenty-first century to broaden the scope of the definition of "refugee" so as to include those variously called "environmental refugees," "environmentally displaced persons," "climate change displaced people," "climate refugees" and "forced climate migrants," no official status has been assigned to them yet (Berchin-Valduga et al. 2017: 148). Many of the people living in the hulk communities in the novel are originally from "the lower-lying lands of the equatorial belt" such as Bangladesh, the Seychelles, the Philippines, Cambodia, Thailand, Egypt, etc. (Hammond 2005: 67), and none of them are regarded as refugees. By refusing to grant them the right to asylum, the xenophobic nations whose practices caused these people to lose their homes in the first place avoid not only facing the consequences of their actions but also taking responsibility for their misdeeds. They reportedly feel "intimidated by these hordes of homeless, status-less people roaming the oceans in old, unseaworthy hulks" and thus not "prepared to open [their] borders to these refugees, people who were regarded as voluntary, unofficial migrants" (Hammond 2005: 68). The way the rich nations see hulk people as "voluntary, unofficial migrants" is quite ironic given the fact that it is the multinational corporations based in these rich nations that caused global warming and forced the people to flee their homelands. Since these hulk communities are not welcome anywhere (when they approach a coast, they are immediately met with hostility and driven away), they "lash[ed] their many ships together to form a single platform ... [which] could float across the giant undulations of the oceans like a leaf on the surface of a flood" (Hammond 2005: 81). Only by doing so could they manage to survive in the turbulent southern oceans.

Paying no heed to the ecological warnings over the last decades, the corporations in the novel continue their climate management practices in full force which 
seriously enfeeble the magnetic field of the Earth with fatal outcomes. NASA researchers have found that the magnetic field, in fact, has "[a] small but evolving dent" and "an unusually weak spot . . . called the South Atlantic Anomaly" which is presumably brought about by the motion of the outer core of the Earth and disrupts only the functioning of satellites for the time being (Johnson-Groh-Merzdorf 2020: par. 1-2). However, in the novel, Hammond magnifies the weakening of the magnetic field by scaling up the level of disruption, and attributes it to extensive anthropogenic changes. For instance, Fivetrees' findings demonstrate that

by reflecting so much additional solar radiation towards the Earth the massive increase in electrically charged particles is warping the magnetosphere, the Earth's magnetic shield. In turn, these new forces are pulling at the magnetic fields deep in the planet's mantle and this is the direct cause of the devastating volcanic eruptions and earthquakes we have been suffering lately. (Hammond 2005: 146)

Indeed, in the course of the novel, innumerable ecological disasters occur, resulting in millions of casualties. Early in the novel, an earthquake of magnitude 9.1 which "is by far the largest and most powerful earthquake ever measured by modern science" hits San Francisco, killing 650,000 people in total (Hammond 2005: 131). Another earthquake occurs about seventy miles off the coast of Hawaii, triggering a tsunami that deluges its northern coastlines and destroys the towns along the coast (Hammond 2005: 184-185). Another series of earthquakes happen in regions ranging across “Turkey, Albania, Montenegro, Italy, Egypt and the Aegean Islands . .." (Hammond 2005: 267). In a sense, all of these disasters across the world attest to the (deliberate) failure of the corporations to recognize the irreversible damage they wreak on the Earth systems.

On the other hand, many unforeseen volcanic activities are detected and a lot of volcanoes around the world become active. For instance, Mount Mariota, "a longdormant volcano" in Independent Samoa, erupts unexpectedly and is "the fourteenth major eruption" in the same year (Hammond 2005: 27). In Naples, Mount Vesuvius erupts for the third time in the last fifty years (Hammond 2005: 51). In Indonesia, Mount Papandayan erupts and causes the deaths of around 250,000 people in its immediate aftermath because of the deadly gas released with the eruption (Hammond 2005: 225). And in the Atlantic Ocean, Cumbre Vieja begins its eruption and makes "[ $\mathrm{t}]$ he entire western flank of Las Palma island, already weakened by millennia of 
volcanic activity, collapse into the Atlantic Ocean ..." (Hammond 2005: 241). These volcanic activities in turn create mega-tsunamis that inundate lands all over the world and swallow whole islands and coastlines, destroying many cities. The mega-tsunami caused by the Cumbre Vieja eruption heads westward, crossing the Atlantic Ocean and flooding the east coast of the Americas. In a chain effect, a series of seismic and volcanic activities is triggered because of the reversal of the Earth's magnetic poles:

At least twenty thousand volcanoes on land or under the seas are currently in major eruption ... One hundred and sixty-two earthquakes above Magnitude 8 have occurred in the last twelve hours ... Sea levels all over the world are rising rapidly ... the Antarctic ice cap is melting ... Finally, our instruments are recording a major disturbance within the Earth's magnetic field .... (Hammond 2005: 274-275)

With these tectonic and volcanic events simultaneously happening across the world, the Earth's land masses are shattered and come crumbling down, hence changing the face of the Earth: "As seismic chaos continued in all parts of the globe, even the largest continental land masses - the Americas, Europe, Russia, Asia, Africa, Australia - had started to disappear beneath the overheated waves" (Hammond 2005: 277). Therefore, since "the Earth is a highly complex and non-linear system with numerous feedbacks which are not fully understood" (Thornes-Pope 2014: 18), the capitalist system's unbridled interference with the world's natural rhythm via its relentless exploitative practices brings the demise of the Earth along with the death and disappearance of millions of people, species, and lands.

\section{Conclusion}

The invasive climate management methods of the companies like the ERGIA Corporation in Hammond's Extinction interfere with and disrupt the natural rhythms of the Earth systems to the extent of the latter's collapse. These self-interested and capital-driven practices are further falsely validated through the fabrication and spread of ignorance in the public by corporations and governments themselves which either suppress the truth about their climate management practices or deliberately distort the facts. In this sense, Hammond's novel lays bare the deadly repercussions of the capitalist economic system's (mis)deeds that inflict irreversible and fatal damage on our only life-support system. Highlighting the power of such accounts, Serenella Iovino writes that stories are "potentially apt to raise our responsiveness about values and 
responsibilities (whether 'environment-society,' or 'human-nonhuman') and envision strategies of change" (2010:761). According to Iovino, as "a creative form of ethical responsibility" and "a [potential] moral (and therefore political) project," such narratives like Hammond's Extinction "not only influence our understanding of a given reality, but also creatively enable a project that takes on society and its values" (2010: 761). In this respect, Hammond's narration provides the reader with a lens through which the reader can see the untold and hidden realities, and grasp better how and at what cost the actions of the capitalist system affect the Earth systems.

To inspire action against environmental destruction and raise eco-consciousness, we need such narratives as Hammond's because " $[\mathrm{t}]$ o consciously interact with the world in which we live, we need stories as much as we need reality" (Iovino 2010: 762). Stories not only "redirect human consciousness to a full consideration of its place in a threatened natural world" (Love 1996: 237), but also encourage us to critically "think about the conscious, unconscious, and structural production of ignorance" (Proctor 2008: 3). Accordingly, Hammond's novel should serve as a cautionary tale instead of being dismissed simply as doom-mongering since global warming, rising sea levels, and rising deep-sea temperatures recounted in the novel have already reached alarming levels in our present age. Ecologically oriented works like Extinction, therefore, harbor the potential to make us see through and beyond the strategic ploys the system uses to inculcate ignorance. And it is time we lend a serious ear to these stories because they are not far from becoming our reality if the system's ignorant practices and ignorance making prevail. 


\section{References}

Adhikari, Surendra, and Ivins, Erik R. (2016), "Climate-Driven Polar Motion: 2003-2015," Science Advances, vol.2, no. 4, pp. 1-10.

Altvater, Elmar (2016), “The Capitalocene, or, Geoengineering against Capitalism's Planetary Boundaries," Anthropocene or Capitalocene? Nature, History, and the Crisis of Capitalism, ed. Jason W. Moore, Oakland, PM Press, pp. 138-152.

Berchin, Issa Ibrahim, Valduga, Isabela Blasi, Garcia, Jéssica, and Guerra, José Baltazar Salgueirinho Osorio de Andrade (2017), "Climate Change and Forced Migrations: An Effort Towards Recognizing Climate Refugees," Geoforum, vol. 84, pp. 147-150.

Garrard, Greg (2004), Ecocriticism, New York, Routledge.

Heise, Ursula K. (2006), “The Hitchhiker's Guide to Ecocriticism,” PMLA, vol. 121, no. 2, pp. 503-516.

Iovino, Serenella (2010), "Ecocriticism, Ecology of Mind, and Narrative Ethics: A Theoretical Ground for Ecocriticism as Educational Practice," ISLE, vol. 17, no. 4, pp. 759-762.

IPCC (2014), Climate Change 2014, Synthesis Report, Summary for Policymakers, Intergovernmental Panel on Climate Change https:/www.ipcc.ch/site/assets/uploads/2018/02/ AR5_SYR_FINAL_SPM.pdf (Last accessed: March 15, 2021).

Johnson-Groh, Mara, and Merzdorf, Jessica (2020, August 19), "NASA Researchers Track Slowly Splitting 'Dent' in Earth's Magnetic Field," https:/www.nasa.gov/feature/ nasa-researchers-track-slowly-splitting-dent-in-earth-s-magnetic-field (Last accessed: March 19, 2021).

Kilifarska Natalya A., Bakmutov, Volodymyr G., and Melnyk, Galyna V. (2020), The Hidden Link between Earth's Magnetic Field and Climate, Amsterdam, Elsevier.

Lazarus, Michael, and Asselt, Harro van (2018), "Fossil Fuel Supply and Climate Policy: Exploring the Road Less Taken," Climatic Change, vol. 150, pp. 1-13.

Love, Glen A. (1996), "Revaluing Nature: Toward an Ecological Criticism," The Ecocriticism Reader: Landmarks in Literary Ecology, eds. Cheryll Glotfelty and Harold Fromm, Athens, University of Georgia Press, pp. 225-240.

Moore, Jason W. (2017), “The Capitalocene, Part I: On the Nature and Origins of Our Ecological Crisis," The Journal of Peasant Studies, vol. 44, no. 3, pp. 594-630.

Oreskes, Naomi, and Conway, Erik M. (2008), “Challenging Knowledge: How Climate Science Became a Victim of the Cold War," Agnotology: The Making and Unmaking of Ignorance, ed. Robert N. Proctor and Londa Schiebinger, Stanford, Stanford University Press, pp. 55-89.

Plumwood, Val (2002), Environmental Culture: The Ecological Crisis of Reason, New York, Routledge. 
Proctor, Robert N. (2008), “Agnotology: A Missing Term to Describe the Cultural Production of Ignorance (and Its Study)," Agnotology: The Making and Unmaking of Ignorance, eds. Robert N. Proctor and Londa Schiebinger, Stanford, Stanford University Press, pp. 1-33.

Proctor, Robert N., and Schiebinger, Londa (2008), Preface, Agnotology: The Making and Unmaking of Ignorance, eds. Robert N. Proctor and Londa Schiebinger. Stanford, Stanford University Press, pp. vii-viii.

Roszak, Theodore (2003), Person/Planet: The Creative Disintegration of Industrial Society, Lincoln, iUniverse.

Sen, Malcolm (2009), "Spatial Justice: The Ecological Imperative and Postcolonial Development," Journal of Postcolonial Writing, vol. 45, no. 4, pp. 365-377.

Shepherd, John (2009), Geoengineering the Climate: Science, Governance and Uncertainty, London, The Royal Society.

Thoreau, Henry David (2008), Walking, Auckland, The Floating Press.

Thornes, John E., and Pope, Francis D. (2014), "Why Do We Need Solutions to Global Warming?," Geoengineering of the Climate System, eds. Ronald E. Hester and Roy M. Harrison, Cambridge, The Royal Society of Chemistry, pp. 1-21. 